\title{
Determinants of Achievement of Basic Immunization in Puskesmas Cot Seumeureung, Aceh Barat
}

\author{
${ }^{1}$ Muhammad Husaini, ${ }^{1}$ Anasril, ${ }^{1}$ Tri Mulyono Herlambang, ${ }^{1}$ Maryono \\ ${ }^{1}$ Poltekkes Kemenkes Aceh, Indonesia
}

Coresponding author: Muhammad Husaini, e-mail: husainiiskandar77@gmail.com

Co-author: AA: anasrilsuri@gmail.com, TMN: trimulyono216@gmail.com, MM: maryonoakpermbo@gmail.com Submitted:19/01/2021 Revised:28/03/2021 Accepted:05/04/2021 Published online: 15/04/2021

doi: https://doi.org/10.35308/j-kesmas.v7i2.1646. How to cite this article: Husaini, M., Anasril, A., Herlambang, T. M., \& Maryono, M. (2021). Determinants of Achievement of Basic Immunization in the Working Area of Puskesmas Cot Seumeureung Samatiga Sub-District West Aceh District. J-Kesmas: Jurnal Fakultas Kesehatan Masyarakat (The Indonesian Journal of Public Health). 8(1): 30-35.

\begin{abstract}
Basic Immunization Achievement data at Puskesmas Cot Seumeureung is 58.9\% with 256 babies. Based on interviews with 2 mothers, the most common problem found in terms of immunization is that mothers are afraid to give immunizations because their babies will have a fever so that their husbands will be angry or in other words, their husbands will not allow them. The purpose of this study was to determine the determinants of basic immunization attainment in the working area of the Cot Seumeureung, Aceh Barat. This type of research is cross sectional, the research was conducted from 30 July to 10 August 2019. With a population of 256 mothers, the sample was taken using purposive sampling technique. Data collection was carried out by distributing questionnaires, univariate and bivariate data analysis. The results of this study indicate that there is an influence of attitudes on the achievement of basic immunization with p value $=0.005(\alpha=0.05)$ and the influence of family support on the achievement of basic immunization with a value of $p$ value $=0.014(\alpha=0.05)$ and there is no effect on the affordability of immunization services towards the achievement of basic immunization with $p$ value $=0.291(\alpha=0.05)$. It is suggested to mothers and families who have babies to be able to increase knowledge about immunization so that the family increases support so that the basic immunization outcomes can be improved again.
\end{abstract}

Keywords: Basic Immunization; Attitude; Support; Distance of Health Service; Puskesmas

\section{Introduction}

Basic immunization is given since the beginning of the baby birth to achieve the immunity level above the protection threshold. The basic immunizations which are prominently given to infants (0-9 months) are HB-0, BCG, DPT-HB-Hib, Campak/MR, and Polio/IPV (Atikah, 2010). Basic immunization is important to protect and decrease the risk of morbidity and mortality from the diseases which actually can be prevented by immunization (Ranuh et al., 2008). Based on the data from UNICEF (United Nations Children's Fund) in 2017, as many as 1.4 million toddlers throughout the world died because of the disease that indeed can be prevented by immunization. This rate is still high enough to cause the death of infants and toddlers resulted by preventable diseases (UNICEF, 2017).

Complete Basic Immunization Coverage for infants reached $86.9 \%$ in 2015 with the setting target at $91 \%$ in 2015 , and $91.6 \%$ in 2016 with the achieving target at $91.5 \%$. However, the immunization coverage decreased again in 2018 in which there were 20 million children who did not get complete basic immunization and some other children did not even get immunization at all (Kementrian Kesehatan RI, 2018).

Basic Immunization Achievement in Aceh in 2017 was $70 \%$ with the distribution of $\mathrm{HB}-0$ antigen: $83,7 \%$, BCG : 77,4 \%, DPT - HB - Hib : $72,9 \%$, polio drops : $72,9 \%$, measles : $70,8 \%$, IPV : $24,6 \%$ (Kementrian Kesehatan RI, 2018). The data of Basic Immunization Achievement obtained from West Aceh District Office in 2018 was 36,8\% with the following antigen distribution: HB $<24$ hours : 26,2(\%), HBO 1-7 days : 68,7 (\%), BCG : 46,6 (\%), Polio 1: 47 ( \% ), DPT - HB - Hib 1: 44,4 (\%), Polio $2: 47,5(\%)$, DPT - HB - Hib 2: 41,3 (\%), Polio 3 : 41,2 (\%), DPT - HB - Hib $3: 40,4$ (\%), Polio $4: 40,9$ $(\%)$ IPV : 23,3(\%) with the target of 4229 infants.

The cumulative data of Basic Immunization Achievement in Cot Seumeureung Public Health Center (PUSKESMAS) as the extension of West Aceh Health Office in 2017 is $41,6 \%$ with the total number of 241 babies. And in 2018 the coverage reached $58.9 \%$ by administering $\mathrm{HB} 0$ antigen $<24$ hours: 63.9 (\%), HBO 1-7 days : 26,3 (\%), BCG: 
$68.6(\%)$, Polio 1: 68,6 (\%), DPT - HB - Hib 1: 71 (\%), Polio 2: 77,6 (\%), DPT - HB - Hib $2: 61,6(\%)$, Polio $3: 61,6$ (\%), DPT - HB - Hib $3: 64,7$ (\%), Polio $4: 65,1$ (\%), IPV : 62,7, measles : 63,5 (\%) with the target of 256 babies.

The number of Integrated Healthcare Center (Posyandu) and the number of babies in the working area of Puskesmas Cot Seumeureung in 2018 is that from 32 villages there are 33 posyandu, with distribution as follow: Alue Raya has 5 people, Cot Amun has 4 people, Cot Darat has 19 people, Cot Lampise has 5 people, Cot Mesjid has 5 people, Cot Pluh has 10 people, Cot Seulamat has 9 people, Cot Seumeureung has 20 people, Deuah has 4 inhabitants, Gampong Cot has 7 inhabitants, Gampong Ladang has 2 people, Gampong Teungoh has 8 people, Keureuseng has 5 inhabitants, Krueng Tinggai has 3 people, Kuala Bubon has 4 people, Leubok memiliki 4 people, Leukeun has 8 inhabitants, Lhok Bubon has 7 people, Mesjid Baro has 7 inhabitants, Pange has 7 people, Paya Lumpat has 12 people, Pinem has 6 people, Pucok Lueng has 11 people, Rangkileh has 3 people, Reusak has 15 inhabitants, Suak Geudebang has 9 inhabitants, Suak Pandan has 9 inhabitants, Suak Pante Breuh has 5 people, Suak Seuke has 6 people, Suak Seumaseh has 10 inhabitants, Suak Timah has 23 inhabitants, Ujung Nga has 4 inhabitants.

The effort of the government of Indonesia in increasing immunization achievement with the help of Health Ministry is by strengthening the role of cross-programs and cross-sectors in rectifying incorrect information about immunization, mobilizing all resources to disseminate the benefit of immunization, ensuring the immunization services are easily accessible to the public, and improving the quality of immunization services. These efforts are in accordance with the goals of Sustainable Development Goals (SDG's), means ensuring a healthy life, supporting welfare for all people of all ages, and reducing Maternal and Infant Mortality Rate (Peraturan Menteri Kesehatan Republik Indonesia Nomor 12 Tahun 2017 Tentang Penyelenggaraan Imunisasi, 2017).

Knowledge, education, occupation, and attitudes are the factors of mothers that will greatly influence the provision of basic immunization for children. Mother's knowledge about the importance of immunization will give her motivation to carry her infants to get immunized. Several problems regarding mother's knowledge such as the mother's ignorance about the importance of immunization, not knowing the right time to get immunization and fear of the side effects that might be caused by giving immunization could be the reasons of being exposed by PD3I (Departemen Kesehatan RI, 2009). A mother plays an important role in maintaining her children's health. One of the ways is by giving her children immunization. Therefore, a mother should focus on several supporting factors which can help her evaluating health problems in her family (Agustina, 2012).

Health concern in a family is greatly influenced by the role of mother. According to Lawrence Green (1980) in Notoatmodjo (2012), health concern is influenced by several factors including facilitating, enabling, and reinforcing factors. The research conducted by Pratiwi in 2012 shows a significant relationship between mothers' education and the provision of immunizations for toddlers. Under educated mothers have a risk of 3,814 times to give incomplete immunization compared to those who graduated from colleges. Mothers' occupation also greatly related to immunization provision, namely 7,667 times higher compared to those who do not work. Other factors like mother's attitude toward immunization, family support, total income, and distance to the immunization service points show varied relationship. Those data indicate that certain factors from mothers greatly determine the provision of completeness of immunization for children (Pratiwi, 2012).

Based on the result of the initial assessment at Puskesmas Cot Seumeureung, Aceh Barat. The immunization achievement is still low $(58,9 \%)$, which means that it is still under the national demand of $95 \%$ in 2018. One of the impacts of the low immunization coverage in the working area of Puskesmas Cot Seumeureung is that in 2017 it was re-discovered diphtheria case suffered by a 15 year child and then followed by several other cases.

The data from interviewing three midwives in the village who are in charge in the Integrated Healthcare Center, it was found that the implementation of integrated healthcare service in Puskesmas Cot Seumeureung is generally good. Each Posyandu has seven cadres and accompanied by one midwife. The distance to healthcare service sites is commonly reachable by the community, although there are also some sites which are not located in residential areas, such as Posyandu of Pinem Village which is located in the middle of rice fields, the Posyandu of Suak Timah and Suak Gedebang. For the implementation of Posyandu in those villages, the cadres use five tables. However, not all Posyandu use this system. 
Based on the result of interviewing two mothers, it showed that the most common problem found related to immunization is that the mothers were hesitate to give immunizations because the babies would have a fever so that their husband would be angry. As a result, their husbands would not allow them to do it. In addition, the closest family such as grandmother also has a great influence in giving immunization in which she assumes that she understands more about the health of the baby than the mother does.

Furthermore, the influence of religious leaders also has an impact on the provision of immunizations, where the opinion of them that giving immunization means injecting forbidden (haram) substance into the body makes people afraid to immunize their children. Economic as well as educational factors also play a role of becoming the cause of unapplied immunization. The babies' families excuse that they do not have time to take them to posyandu because of a full working time.

\section{Methods}

This is an observational analytic study which used a cross sectional approach (Arikunto, 2010). Observation and data collection were conducted at one time (Kuntjojo, 2009).
The populations of this study were all mothers who have infants aged 0-11 months in all working areas of Puskesmas Cot Seumeureung, Samatiga District, West Aceh Regency with the total number of 256 people. The numbers of samples of 42 people are obtained from Slovin sample formula (Notoatmodjo, 2012a).

$$
\mathrm{N}=\mathrm{N} /\left(1+\left(\mathrm{Nxe}^{2}\right)\right.
$$

Technique of data collection was undergone by distributing questionnaires to the mothers who have babies during the posyandu and they were withdrawn shortly after the questionnaires were filled in The instruments of this research were the questionnaire for respondent of demographic data and the questionnaire used to measure attitude using Likert scale. The questionnaire to measure support of the family was using Guttman scale. The data then were analyzed by using chi-square statistical test for each variable

\section{Results}

\section{Uniariate Analysis}

The results of the univarate analysis can be seen in table 1 below. Include characteristics of Respondents consist of age, education, and occupation and else. The result of data about univariate of analisys of this study on respondents can be seen in the following table 1:

Table 1. Univariate analysis

\begin{tabular}{lcc}
\hline Category & Frequency & Percentage(\%) \\
\hline Age & 27 & 64.3 \\
$20-29$ & 15 & 35.7 \\
$30-40$ & & \\
Education & 6 & 14.3 \\
Undergraduate & 19 & 45.2 \\
Senior High school & 10 & 23.8 \\
Junior High School & 7 & 16.7 \\
Elementary School & & \\
Occupation & 7 & 16.7 \\
Civil Servant & 8 & 19.0 \\
Self-employed & 27 & 64.3 \\
Housewife & & \\
Immunization Achievement & 21 & 50,0 \\
Complete & 21 & 50,0 \\
Incomplete & & \\
Immunization Achievement & 21 & 50,0 \\
Complete & 21 & 50,0 \\
Incomplete & & \\
Attitude & 22 & 52,4 \\
Good & 20 & 47,6 \\
Poor & & \\
Family Support & 21 & 50,0 \\
Good & 21 & 50,0 \\
Poor & &
\end{tabular}


The Distance of Service

\begin{tabular}{lll}
$<1 \mathrm{KM}$ & 15 & 35,7 \\
$1-4 \mathrm{KM}$ & 10 & 23,8 \\
$>4 \mathrm{KM}$ & 17 & 40,5 \\
\hline
\end{tabular}

(Source: Data analysis, 2021)

Table 1. Univariate analysis

\begin{tabular}{|c|c|c|c|c|c|c|c|c|}
\hline \multirow{3}{*}{$\begin{array}{l}\text { Family } \\
\text { Support }\end{array}$} & \multicolumn{4}{|c|}{ Immunization Achievement } & \multirow{2}{*}{\multicolumn{2}{|c|}{ Frequency }} & \multirow{3}{*}{ P-value } & \multirow{3}{*}{ Odds Ratio } \\
\hline & \multicolumn{2}{|c|}{ Complete } & \multicolumn{2}{|c|}{ Incomplete } & & & & \\
\hline & $\mathrm{n}$ & $\%$ & $\mathrm{n}$ & $\%$ & $\mathrm{n}$ & $\%$ & & \\
\hline \multicolumn{9}{|c|}{ Family Support } \\
\hline Poor & 15 & 71,4 & 6 & 28,6 & 21 & 100 & \multirow{3}{*}{0,014} & 6,250 \\
\hline Good & 6 & 28,6 & 15 & 71,4 & 21 & 100 & & $(1,638-23,843)$ \\
\hline \multicolumn{8}{|l|}{ Attitude } & \\
\hline Poor & 15 & 75 & 5 & 25 & 20 & 100 & \multirow{2}{*}{0,005} & 8 \\
\hline Good & 6 & 27,3 & 16 & 72,7 & 22 & 100 & & $(2,012-31,803)$ \\
\hline \multicolumn{9}{|c|}{ The Distance of Service } \\
\hline$<1 \mathrm{KM}$ & 9 & 60 & 6 & 40 & 15 & 100 & \multirow{3}{*}{0,291} & \\
\hline $1-4 \mathrm{KM}$ & 6 & 60 & 4 & 40 & 10 & 100 & & \\
\hline$>4 \mathrm{KM}$ & 6 & 35,3 & 11 & 64,7 & 17 & 100 & & \\
\hline
\end{tabular}

(Source: Data analysis, 2021)

Based on table 1. That indicates most of the respondents are young adults $(64.3 \%)$, have a high school educational background $(45,2 \%)$ and work as housewives $(64,3 \%)$, the total number of the complete immunization achievement is $50 \%$. The determinants of immunization achievement are divided into three factors, namely attitudes, family support, and distance to health services. Based on the table above, it indicates that most of the respondents have a good attitude toward immunization (47.6\%). A good family support only reaches $50 \%$. And most of the respondents $(40,5 \%)$ reach the distance $>4 \mathrm{KM}$.

Based on table 2 above shows the result that there is a correlation between the attitude and the achievement of basic immunization (p-value : 0,014), there is a correlation between family support and the achievement of basic immunization (p-value 0,005), in the Work Area of Puskesmas Cot Seumeureung, Aceh Barat, correlation between the distance of health services and the achievement of basic immunization in (p-value the Work Area of Puskesmas Cot Seumeureung, Samatiga District, West Aceh Regency.

\section{Discussion}

The result of this study shows that there is the correlation between mothers' attitude and the basic immunization achievement in the Work Area of Puskesmas Cot Seumeureung, Aceh Barat with the p- value $=0.005$. It means that mother's attitude greatly affects the basic immunization achievement of her baby. The Odds Ratio (OR) value 8,000 means that mothers with a good attitude have eight times chances to complete the basic immunization achievement for their babies compared to those who react not in a good way.

The result of this research has the similarity with the studies of Miftahol Hudhah and Atik Choirul Hidajah who say that there is the correlation between mother's attitude and the complete basic immunization achievement with $\mathrm{p}$ value $=0.000$ (Hudhah \& Hidajah, 2017). This research is also supported by (Octaviani, 2015) who states that mother's attitude affects mother's refusal to follow a complete basic immunization achievement.

Attitude is defined as someone's opinion or assessment of the environment and its relationship to health (Khamisa et al., 2013). According to Notoatmodjo (2010), before someone adopts a new behavior, there is a sequential process in his/her body, namely awareness, interest, evaluation (considering the good or bad impact of the stimulus towards him/her), trial (starting to try a new behavior), and adoption (the subject has applied a new behavior in accordance with his/her knowledge, awareness, and attitude toward the stimulus). The levels of attitude according to Notoatmodjo (2010) are receiving, responding, valuing, and being responsible.

In this study, it was found that majority of mothers with good attitude were 22 people (52.4\%), 
with the knowledge level of respondent is in the middle one. Other factors which affect the attitude is the influence of other people which are considered important such as the adequate role of cadres, village midwives, and the immunization program holders in providing information and understanding so that all these factors affect mothers' attitude. If the health cadres, midwives, and immunization program holders can play their role as the key of preventive efforts (immunization services) then all mothers can behave well in immunizing their children. In addition, attitudes also can be influenced by the factor of personal experience, the influence of other people who are considered important, cultural influences, mass media, educational and religious institutions, and emotional factors.

The result showed that there is a correlation between family support and basic immunization outcomes in the Work Area of Puskesmas of Cot Seumeureung with $\mathrm{p}$ value $=0.014$. It means that family support affects the basic immunization outcomes for the baby. The Odds Ratio (OR) value of 6.250 means that mothers with a good family support have 6.250 times the chance to complete basic immunization achievement for the babies compared to those who do not have good family support. The result of this study is similar to those of Dinengsih and Hendriyani who state that there is a significant correlation between family support and mother's constancy to do basic immunization with the $\mathrm{p}$ value $=0.000$ (Dinengsih \& Hendriyani, 2018). Family support is an attitude and acceptance of family members in the form of informational, appraisal, instrumental, and emotional supports. These whole elements are manifested in the form of interpersonal relationship which includes attitude, action, and acceptance toward family members, so that family members feel that their family are paying a good attention (Friedman, 2010).

A mother who has a positive attitude toward her children's immunization needs to get support from her husband in form of confirmation or permission, family support from parents/ in-laws who also have the same attitude toward immunization, and supported by facilities which can ease immunization coverage and motivation to immunize the baby routinely (Smeltzer et al., 2011). House and Kahn (1985) in Friedman (2010) explains that family has four support functions: emotional, informational, instrumental and assessment support.

Mothers with family support have the possibility to immunize their children completely. This support results in positive action in health behavior. Otherwise, some other mothers are disobedient to do basic immunization because they lack of support from the family. Lack of support from the family is caused by insufficient information about immunization and lack of trust toward health workers.

Based on the data analysis using statistical chi square test, $p(0,291)>\alpha(0,05)$, it means that there is no significant correlation between health service coverage and basic immunization completeness in Work Area of Puskesmas Cot Seumeureung. The results of this study are not in line with Wahyuni Hafid's research (2016) who states that the access to health services statistically influence the complete basic immunization status of the baby with the $\rho$ value $=0,007$ (Hafid, 2016). The research conducted by Nainggolan in 2016 shows that there is the time to access to UKBM ( $\rho$ value 0,000$)<(\alpha 0,05)$. This result means that the UKBM travel time has the correlation with the status of complete basic immunization of a-two-years infants aged 12-23 months (Nainggolan et al., 2016).

Based on the analysis, the correlation between the distance of health services and the completeness of basic immunization showed that there is no significant correlation between the distance of health services and the completeness of basic immunization in Work Area of Puskesmas Cot Seumeureung. In this study, it was found that the tendency of parents who have the house close to the health service sites to get immunization. It is also supported by the length of time and the amount of cost to reach the place. The longer the time to reach the place, the bigger the cost needed up to the standard amount, so the difficulty to come to the site is increasing. However, even if the distance from home to the immunization service site is quite far, if it can be reached easily, the immunization can still be undergone.

\section{Conclusion}

Based on the result of this research, it can be concluded that there is the correlation between mothers' attitude and the achievement of basic immunization in Puskesmas Cot Seumeureung, Samatiga District, West Aceh with the $\mathrm{p}$ value = 0.005 .

There is also the correlation between family support and the achievement of basic immunization in the working area of Puskesmas Cot Seumeureung, Samatiga District, West Aceh with the p-value = 0.014 . However, it was not found the correlation between the distance to the immunization service points and the achievement of basic immunization the working area of Puskesmas Cot Seumeureung, Samatiga District, West Aceh. 


\section{Acknowledgement}

Praise to the Almighty Allah for His guidance and mercy. Thanks to all friends and colleagues who have contributed to this research until it is published. Thanks to Poltekkes Kemenkes Aceh stakeholders for the research funding assistance.

\section{Author Contribution and Competing Interest}

The first researcher has the largest contribution in this research, starting from the preparation of the proposal to the report of the research results. The second and third writers have contributed in collecting the data, processing and assisting the first writer in completing this article. The author assures that there is no conflict of interest in the activities and preparation of this report.

\section{Publisher's Note}

J-Kesmas: Jurnal Fakultas Kesehatan Masyarakat (Indonesia Journal of Public Health) remains neutral with regard to jurisdictional claims in published institutional affiliation.

\section{References}

Agustina. (2012). Pengetahuan dan Sikap Ibu Terhadap Pemberian Imunisasi Dasar Bayi di Wilayah Kerja Puskesmas Montasik Kabupaten Aceh Besar. Stikes U'Budiah.

Arikunto. (2010). Prosedur Penelitian Suatu Pendekatan Praktek. Rineka Cipta.

Atikah. (2010). Imunisasi dan Vaksinasi. Nuha Medika.

Departemen Kesehatan RI. (2009). Pedoman Pengelolaan Vaksin.

Dinengsih, S., \& Hendriyani, H. (2018). Hubungan antara pendidikan, pengetahuan, dukungan keluarga dan peran tenaga kesehatan dengan kepatuhan ibu dalam melakukan imunisasi dasar pada bayi usia 0-12 bulan di desa Aweh Kabupaten Lebak Provinsi Banten. Jurnal Kesehatan Kusuma Husada, 202-212.

Friedman, M. M. (2010). Buku Ajar Keperawatan Keluarga: Riset, Teori, dan Praktek. EGC.

Hafid, W. (2016). Indikator Prediktif Imunisasi Dasar Lengkap Pada Bayi Di Puskesmas Konang Dan Geger Kabupaten Bangkalan. Universitas Airlangga.

Hudhah, M. H., \& Hidajah, A. C. (2017). Perilaku ibu dalam imunisasi dasar lengkap di puskesmas Gayam Kabupaten Sumenep. Jurnal
Promkes: The Indonesian Journal of Health Promotion and Health Education, 5(2), 167180.

Kementrian Kesehatan RI. (2018). Pedoman Pencegahan dan Pengendalian Difteri.

Khamisa, N., Peltzer, K., \& Oldenburg, B. (2013). Burnout in relation to specific contributing factors and health outcomes among nurses: a systematic review. International Journal of Environmental Research and Public Health, 10(6), 2214-2240.

Kuntjojo. (2009). Metodologi Penelitian Kuantitatif dan Kualitatif. Graha Ilmu.

Peraturan Menteri Kesehatan Republik Indonesia Nomor 12 tahun 2017 tentang Penyelenggaraan Imunisasi, (2017).

Nainggolan, O., Hapsari, D., \& Indrawati, L. (2016). Pengaruh akses ke fasilitas kesehatan terhadap kelengkapan imunisasi baduta (analisis riskesdas 2013). Media Penelitian Dan Pengembangan Kesehatan, 26(1), 15-28.

Notoatmodjo, S. (2010). Promosi Kesehatan. Rineka Cipta.

Notoatmodjo, S. (2012a). Metodologi Penelitian Kesehatan. Rineka Cipta.

Notoatmodjo, S. (2012b). Promosi Kesehatan. Rineka Cipta.

Octaviani, F. A. (2015). Faktor Yang Mempengaruhi Penolakan Ibu Terhadap Pemberian Imunisasi Dasar Lengkap Di Wilayah Puskesmas Kamoning Kabupaten Sampang Tahun 2014. UNIVERSITAS AIRLANGGA.

Pratiwi, N. L. (2012). Faktor-faktor yang Berhubungan dengan Status Imunisasi Dasar pada Balita Umur 12-23 Bulan di Indonesia Tahun 2010 (Analisis Data Riskesdas 2010). UI.

Ranuh, I. G. ., \& Et.al. (2008). Pedoman Imunisasi di Indonesia. In Satgas IDAI. Jakarta. Ikatan Dokter Anak Indonesia.

Smeltzer, Suzanne, B. C., \& Brenda, G. (2011). Buku Ajar Keperawatan Medikal Bedah. RGC.

UNICEF. (2017). Immunization.

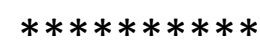

